$\mathrm{BFJ}$

123,4

\title{
Do consumers really recognise a distinct quality hierarchy amongst PDO sparkling wines? The answer from experimental auctions
}

\author{
Luigi Galletto \\ Research Center for the Viticulture and Enology (CIRVE), University of Padova, \\ Conegliano, Italy \\ Francesco Caracciolo \\ Agricultural Sciences Economics and Policy, \\ Università degli Studi di Napoli Federico II, Napoli, Italy \\ Vasco Boatto and Luigino Barisan \\ Research Center for the Viticulture and Enology (CIRVE), University of Padova, \\ Conegliano, Italy \\ Deborah Franceschi \\ Department of Agronomy, Food, Natural resources, Animals and Environment \\ (DAFNAE), University of Padova, Conegliano, Italy, and \\ Marica Lillo \\ Research Center for the Viticulture and Enology (CIRVE), University of Padova, \\ Conegliano, Italy
}

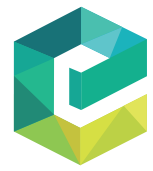

British Food Journal Vol. 123 No. 4, 2021 pp. $1478-1493$ Emerald Publishing Limited 0007-070X

DOI 10.1108/BFJ-07-2020-0625

\begin{abstract}
Purpose - Consumer likeability and willingness to pay (WTP) for two Italian sparkling wines, (Conegliano Valdobbiadene Prosecco DOCG and Prosecco DOC) are evaluated through a non-hypothetical Becker-DeGrootMarschak (BDM) auction during a wine-tasting experiment. The purpose of this paper is to estimate individual WTP and relate it to likeability for both wines, with and without supplying additional information on their features. Design/methodology/approach - Data were collected in May-June 2019 from a sample of 99 consumers in Northern Italy. A non-hypothetical BDM auction in a wine-tasting experiment was implemented.

Findings - The results show that the additional information plays a significant role in widening the WTP gap between the two geographical indications (GIs), while the blind tasting narrows this gap. The "superiority" of the Conegliano Valdobbiadene Prosecco DOCG is confirmed but relies more on its better reputation than its better taste. Research limitations/implications - The authors are aware of two main limitations in the study. The first is the territorial composition of the consumer sample. The second is the selection of the Prosecco bottles used in the experiment. The results are considered pioneering and need to be verified by additional experiments with different consumer and bottle samples.

Practical implications - Promotional suggestions for the Tutelary Consortia of the two GIs stem from the results. The Prosecco DOC should primarily stress its likeability, while the Conegliano Valdobbiadene Prosecco DOCG should primarily emphasise the reasons for its "superiority".
\end{abstract}

(C) Luigi Galletto, Francesco Caracciolo, Vasco Boatto, Luigino Barisan, Deborah Franceschi and Marica Lillo. Published by Emerald Publishing Limited. This article is published under the Creative Commons Attribution (CC BY 4.0) licence. Anyone may reproduce, distribute, translate and create derivative works of this article (for both commercial and non-commercial purposes), subject to full attribution to the original publication and authors. The full terms of this licence may be seen at http://creativecommons. org/licences/by/4.0/legalcode

We want to thank both the Consortia of Conegliano Valdobbiadene Prosecco Docg and Prosecco Doc, and Professor Vanino Negro and Dr Luigi Stramare for their cooperation. 
Originality/value - To the best of the authors' knowledge, no previous study has related likeability and WTP for similar GI wines produced in contiguous areas. Moreover, the current research has applied a nonhypothetical BDM auction in a wine-tasting experiment.

Keywords Geographic indication, Prosecco sparkling wine, Likeability, WTP, Wine-tasting experiment, Nonhypothetical BDM auction

Paper type Research paper

\section{Introduction}

Today, the European Union's wine producers are facing severe worldwide competition, in which the increased number of Protected Denominations of Origin (PDOs), sub-appellations and the range of wines (i.e. blend and varietal wines, types and versions) play crucial roles in shaping wine markets (Johnson and Bruwer, 2007). Over the last 20 years, the number of EU wine quality labels has risen noticeably, and this trend is expected to continue in the coming years. While the creation of new PDOs can generate both consumers' preference heterogeneity and producers' competitive advantages (Porter, 2008; Caracciolo et al., 2016), the introduction of new appellations can also produce conditions in which consumers cannot distinguish different schemes and fail to attain value-added wines, at least in the short run (Aprile et al., 2009; Resano et al., 2012).

Prosecco sparkling wine can be considered an emblematic product for both the positive and negative effects of the introduction of new PDOs. To illustrate, the Prosecco sparkling wine market has experienced in recent years a dramatic increase in the dynamics of production and export (Del Rey, 2015; Pomarici et al., 2019). The accomplishment of the Prosecco Reform of 2009, aimed at protecting the value of its name, has contributed to this success. Indeed, before 2009, the Prosecco grapevine was grown exclusively in Treviso Province, with two different certifications, Protected Geographical Indication (PGI) and PDO, with the latter reserved for the grapes cultivated in a very small area between two municipalities (Conegliano and Valdobbiadene). With the Prosecco Reform, the PDO production area was elevated to "Superiore PDO", while a new PDO has appeared that broadens and substitutes for the previous Prosecco PGI (Rossetto et al., 2011).

Thus, to date, Prosecco PDO can be presented to consumers through three Denominations of Origin: Conegliano Valdobbiadene Prosecco DOCG, which was recently recognised as a UNESCO World Heritage Site, and Asolo Prosecco DOCG (both Superiore PDOs) and Prosecco Doc, which have the same winemaking vocation linked to the cultivation of vines, the Glera grape variety and the production of Prosecco, but with significant historical, cultural and terroir differences. However, given the similar sensory characteristics [1] that contribute to consumers' appreciation of all Prosecco production, companies suffer from the reduction of intra-PDO differentiation of Prosecco wines, which has, in turn, reduced the effectiveness of the communication of the intra-PDO quality signals of Prosecco sparkling wines. Hence, the signalling of quality distinctiveness by Prosecco sparkling intra-PDO wines can also become unclear to the consumer (Dal Bianco et al., 2018), who could sustain higher transaction costs when examining differences amongst Prosecco PDO wines. This paper aims to investigate specifically if Prosecco consumers noticeably appreciate intra-PDO differences between Conegliano Valdobbiadene Prosecco Superiore DOCG (PS-DOCG) and Prosecco Spumante Doc (P-DOC). More specifically, the present research aims to contribute to the recent flow of the literature analysing Prosecco sparkling wine demand and consumer preferences for the different Prosecco geographical certifications (Rossetto and Gastaldello, 2018; Thiene et al., 2013a, b). Differently from previous contributions in the literature, our study aims to understand if the differences between the two Prosecco PDOs' hierarchical levels are recognised by consumers in terms of willingness to pay (WTP) and how the sensory characteristics as well as the provision of additional information may influence consumers' perceptions and preferences. To this end, the study uses both sensory and experimental economics approaches.
Distinct quality hierarchy amongst wines? 
$\mathrm{BFJ}$

123,4

1480

Experimental auctions (EA) are largely used to measure consumers' preferences in a nonhypothetical scenario, with participants facing real economic incentives to disclose their real preferences (Corrigan and Rousu, 2006; Gracia et al., 2011; Lewis et al., 2016; Lusk, 2003; Lusk et al., 2007; Shogren et al., 1994). Some authors (Lusk et al., 2004; Lusk and Hudson, 2004) have demonstrated the usefulness of EA as a valuable tool to support policymakers in their marketing decisions, whether in public institutions or private firms.

The paper is structured as follows. In the first section of the article, the literature background is given. The second section illustrates materials and methods, while in the third section, the major findings from data analysis are presented. Finally, the concluding discussion of the work is reported.

\section{Literature review}

\subsection{Consumers' preference on sparkling wines}

The previous literature has largely showed that consumers have heterogeneous preferences with respect to sparkling wine (Caracciolo and Furno, 2020): factors such as consumer demographic characteristics and psychological attitudes may largely shape preferences and consumption behaviour for sparkling wines (Zepeda and Deal, 2009). For example, as concerns demographic characteristics, young Korean wine consumers (aged 20-29 years) have shown a stronger preference for sparkling wines than older consumers (Lee et al., 2005). These results have been confirmed by more recent research conducted in the North American market, where some authors have shown differences in sparkling wine consumption in Canada between genders and generations (i.e. millennial and older consumers) (Bruwer et al., 2011, 2012). The study by Charters et al. (2011) confirmed the effect of gender on consumer preferences, showing transcultural similarities. Sparkling wines were considered women's drinks, in line with previous findings by (Hoffman, 2004), who considered that women are more likely to drink sparkling wines than men.

Indeed, in the purchasing decision-making process, socio-demographic and cultural characteristics may play a mediating role between consumer psychological attitudes and the consumption of sparkling wines (Zepeda and Deal, 2009). For instance, a study targeting four English-speaking countries (United States, United Kingdom, Australia and New Zealand) has provided empirical evidence that the cultural differences of young consumers may influence the perception of Champagne and sparkling wines (Velikova et al., 2016). Using socio-demographic covariates and attitudinal scores Thiene et al. (2013), identified WTP patterns concerning differences between Prosecco PDOs and PGI, while the research of Olarte et al. (2017) identified the role of social norms in shaping the purchasing intentions of sparkling wine consumers, although with less importance than other factors such as sensory characteristics and price. Social norms as well as other psychological factors are important drivers, as argued in a recent study conducted in Australia by Verdonk et al. (2017), which showed that positive social image, reputation and symbolism are particularly relevant for Champagne consumption.

The above-mentioned literature shows the influence of consumer characteristics on consumer purchasing behaviour for sparkling wines. However, product characteristics are also becoming increasingly relevant, since the sparkling wines market is becoming increasingly differentiated in terms of intrinsic and extrinsic attributes, quality, complexity and price range.

Along these lines, Culbert et al. (2017) and Vecchio et al. (2019) focussed on the role of production methods (Charmat or traditional method) in affecting the sensory profile and therefore the quality perception of sparkling wines. Similarly, Thiene et al. (2013) highlighted the importance of certification of origin and type of production (sparkling and semi-sparkling) in affecting Prosecco choices. A few studies have highlighted the role played by region or country of origin and their supporting certifications in sparkling wines. Rossetto and Gastaldello (2018), for instance, identified a positive effect of the PDO certification reputation in influencing Prosecco consumers' loyalty. Similarly, Chamorro et al. (2015) considered multiple 
origin designations of Cava sparkling wines and demonstrated that consumers' preference structure is largely influenced by the area of origin. In particular, the study showed that when consumers recognise the differentiation in denominations of origin, they show a higher involvement with the product in terms of consumption frequency and purchasing value. The consumers' recognition of the quality attributes is a crucial issue while, as the next paragraph will illustrate, consumers often might misperceive the information signal associated to GIs.

\subsection{Consumers' perception towards geographical indications}

The "quality perception gap" between consumers and producers represents a crucial issue to be investigated for the well-functioning of any markets (Steenkamp, 1990). With respect to wine, this topic mainly involves how the GIs are recognised and perceived credible by consumers. To this regard, Caracciolo et al. (2016) empirically proved that consumers appreciation of wines increases as the level of origin designation increases from lower (PGI) to higher quality (DOCG). This result is largely consistent with findings of other studies (Cembalo et al., 2014), even if, there are many exceptions: for instance, Saenz-Navaja et al. (2014) showed that while wine geographical origin is one of the main quality cue for less-involved consumers, more-involved consumers may use a wider range of cues for identifying the highest quality wines. In general terms, the longer the GI history, the higher its awareness and its positive impact on consumers' choice (Costanigro et al., 2017). However, reforms of GI systems regularly occurred with the final aim to increase vertical differentiation while consumers may be confused or misled since only a smaller proportion of them are generally prepared towards an ever-increasing variety of wines choice (Johnson and Bruwer, 2007; Teuber, 2011).

For instance, Costanigro et al. (2019) demonstrated that the introduction of an upper-tier quality geographic classification (i.e. Chianti Classico's Gran Selezione wines) increased the perceived quality of the new product while, at the same time, it decreased the quality perception of lower-tier wines. Similarly, a change of the hierarchical levels within Burgundy GIs might generate significant changes in the consumers' perception of the quality levels. In particular, the promotion of medium-tier wines to higher quality wines is beneficial for those wines, while the loss is limited to wines in the other levels (Saidi et al., 2020). These results were confirmed by Gokcekus and Finnegan (2017) by analysing the impact of introducing new sub-divisions within Oregon's Willamette Valley American Viticultural Area.

By means of a non-hypothetical Becker-DeGroot-Marschak (BDM) auction in a winetasting experiment, this paper contributes to this debate (Galletto, 2005; Scarpa et al., 2009) by investigating if the quality signalling within the different Prosecco sparkling intra-PDO certifications is effective, or, in other words, if consumers appreciably recognise a distinct quality hierarchy amongst Prosecco PDOs as introduced by the Reform of the 2009.

\section{Materials and methods}

Consumers' preferences for different Prosecco PDOs are elicited here using an EA within a non-hypothetical experiment. In particular, preferences are measured in monetary metrics in terms of individuals' WTP by using the BDM mechanism in a mixed within/between-subjects experimental design (Charness et al., 2012; Rousu et al., 2004). By using monetary metrics and observing effective purchases, consumers are fully incentivised to truthfully reveal their real preferences (Caracciolo et al., 2019).

Within the BDM procedure, participants simultaneously presented an offer price in a closed envelope. Then, a sale price was randomly drawn from a uniform distribution, ranging from three to ten euros in increments of $€ 0.50$. The above-mentioned range was unknown to the participants. Any participants who provided an offer price greater than the sale price received the product by paying the sale price. Because the sale price was drawn at random, participants were informed that it was in their interest to offer the real price that they were 
BFJ

123,4

1482

willing to pay for the products. This mechanism is incentive-compatible since bidders have no reason to underestimate their real WTP because the sale price is determined by a random drawing and not by the same participants (Shogren et al., 1994; Becker et al., 1964; Corrigan and Rousu, 2006). The BDM procedure is widely used by food researchers (Vecchio et al., 2019; Caracciolo et al., 2019) and is easily implemented, particularly within a real market (such as shops and restaurants), which allows the experimenters to carry out a study applying a random sampling method (Lusk, 2003). Amongst the main disadvantages is that participants in the BDM auctions may tend to deviate from their true WTP (Bohm et al., 2004) for the socalled anchoring effect. The distortion occurs because the participants may refer to other people's WTP, as participants can use this information to adjust their own evaluations. Therefore, as mentioned above, the researcher should try to avoid reference prices (Drichoutis et al., 2008; Harrison and List, 2004).

Moreover, consumers' expected liking and informed liking for the different Prosecco PDOs are collected. Following criteria established in Harrison and List (2004), the main characteristics of the experiment will be illustrated in the next sub-paragraph, including the characteristics of the participants and of the evaluated wines, the rules of the BDM auction, the activities carried out by participants and the information provided.

\subsection{Participant characteristics}

Overall, 99 sparkling wine consumers were recruited to participate in an EA at the University of Padova's sensory analysis room (UNIEN ISO 8589: 2014) in Conegliano (a small town to the north of Treviso), avoiding non-wine drinkers (Depositario et al., 2009).

The sample was almost entirely formed of participants living in the Veneto region, between the PS-DOCG (49\%) and P-DOC $(51 \%)$ areas (Table 1$)$. The EA was conducted in 2019. Amongst participants, there was a higher proportion (39\% of total) of young people (aged 18-25 years) compared to other age groups, 29\% (aged 25-50 years) and 31\% (older than 50 years), respectively. In the sample, there were more men $(60 \%)$ than women. The cohort of frequent drinkers was the most prominent: $23 \%$ consumed wine habitually (every day) and $56 \%$ two or three times a week, whereas the occasional drinkers $(17 \%)$ and infrequent drinkers (3\%) accounted for lower percentages. Most of the participants ( $81 \%)$ had not received specific training on wine.

\subsection{Product characteristics}

In accordance with the Consortium's sparkling specifications and their wine production features, 14 Prosecco PDO producers with similar characteristics (i.e. own vineyards and considerable direct sales' share) and wines were selected to represent the wide heterogeneity of Prosecco production: seven sparkling wines from the P-DOC and seven sparkling wines from the P-DOCG. The selection of the wines for the two Prosecco PDOs has been planned, by considering different producers in each Prosecco PDOs level, to avoid the producer effect (Saidi et al., 2020). Each producer provided 15 bottles of sparkling wine (standard format of 0.751 ) made from Glera grapes $(100 \%)$. In particular, the sparkling brut (nonvintage) line was used in the experiment, given consumers' higher familiarity with this specific product line, which is characterised by low residual sugar (between 6 and $12 \mathrm{~g}$ per litre) (Boatto et al., 2018; Lusk and Shogren, 2007; Plott and Zeiler, 2005; Zhao and Kling, 2004).

Table 2 summarises the characteristics of the 14 wines chosen for the experiment. Although, on average, the residual sugar between P-DOC and PS-DOCG wines is the same, the latter has an average price that is $56 \%$ higher. The difference in the price between the two typologies reflects the current market [2].

The front label, indicating the Prosecco PDOs certification and the producer brand, and the back label were hidden during the auction. 


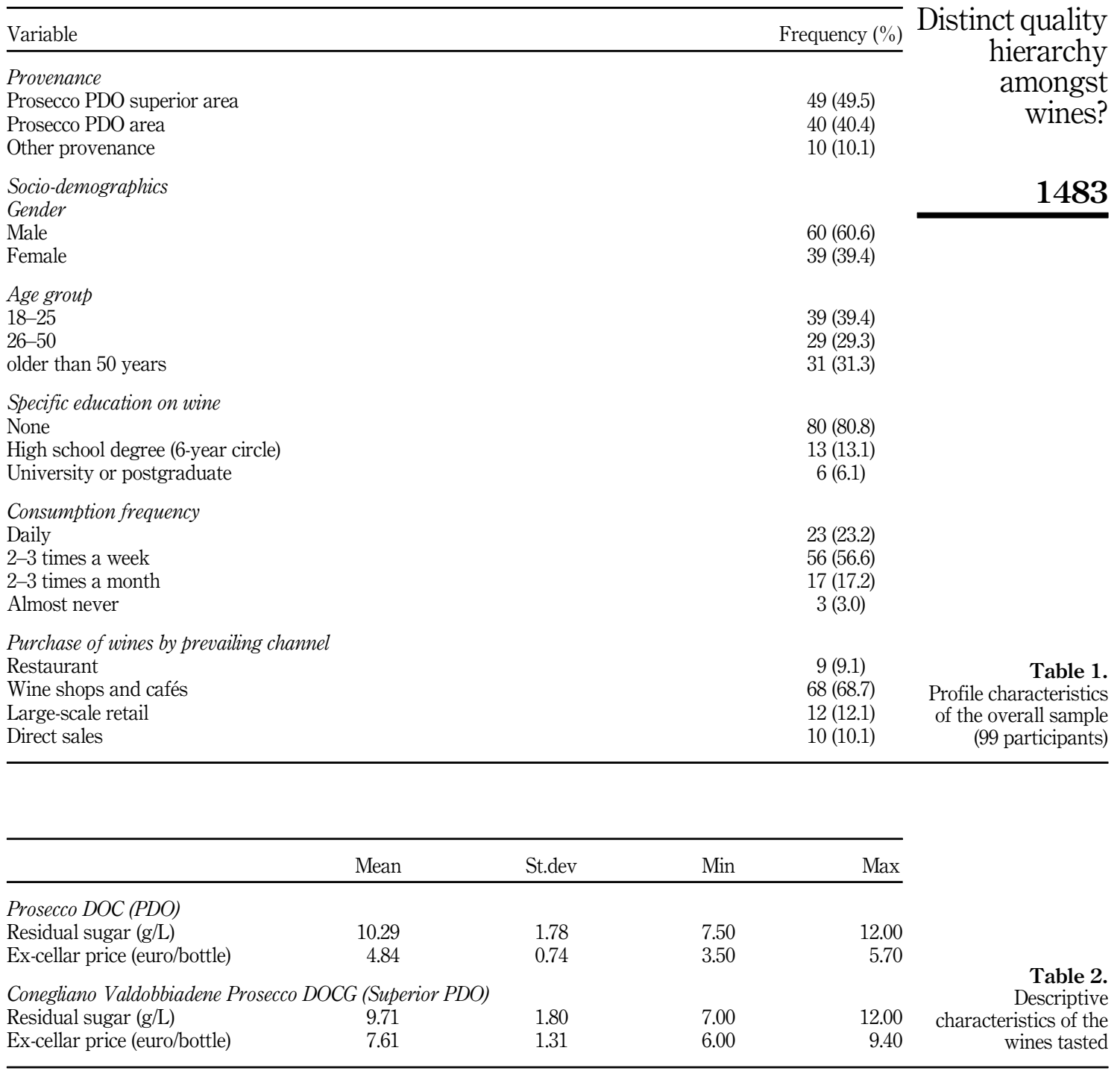

\subsection{The study design}

The study was based on a mixed within/between-subjects design without any deceptive practice or unfaithful communication of information. As discussed in the second paragraph, the study assumes that, holding all other things constant, consumers' preferences can be influenced by taste likeability and PDO information (Lange et al., 2002). For this reason, participants joined two consecutive rounds, in each of which they were asked to bid on two Prosecco wines, a P-DOC and a PS-DOCG. However, the two rounds differed in the amount and type of information participants received.

In the first round, the participants were asked to indicate their bid based only on their background knowledge of Prosecco PDO wines and without tasting the product (round 1: no 
$\mathrm{BFJ}$ 123,4

1484

taste; no additional information). In the second round, the participants received more information on the two products but did not taste them (round 2: additional information) and then indicated their WTP. In the third and last round, participants tasted the wines after blind tasting (round 3: blind tasting) and then indicated their offer price for the two wines and their overall liking for each wine. To summarise, each participant submitted 6 bids $(2$ wines $\times 3$ rounds), and, when they tasted the wine, they also reported a hedonic rating in terms of overall liking. The detailed information provided to the participants on the two Prosecco Denominations is shown in Table 3 (Roth et al., 1995), while their overall liking was measured through a 9-point hedonic categorical scale with the following anchors: "I find it extremely unpleasant" (=1), "I find it very unpleasant" (=2), "I find it unpleasant" (=3), "I find it slightly unpleasant" (=4), "It leaves me indifferent" $(=5)$, "I find it slightly pleasant" $(=6)$, "I find it pleasant" $(=7)$, "I find it very pleasant" $(=8)$, and "I find it extremely pleasant" $(=9)$.

Participants received cash compensation of $€ 10$. However, as this might overestimate WTP values, participants were asked to indicate how they would spend the cash in the near future. This approach minimises the windfall or house money effect (Lombardi et al., 2019). Half of the sample played the last two rounds in reverse order (round 3-blind tasting before, then round 2 - information) to control for any potential order effects.

At the beginning of the experiment, participants were given a questionnaire to collect essential consumer sociodemographic information (age, gender, origin), wine knowledge, and consumption attitudes and habits. Specifically, consumers were asked about their specific training in wine, extracurricular knowledge, where they usually buy wine and their intention to improve their wine knowledge and tasting skills. To prevent collusion between participants, no form of communication was permitted amongst the bidders during the auction. To avoid the affiliation effect, price feedback was not provided to participants in the three rounds (Lusk and Shogren, 2007). Moreover, the wealth effect was controlled by randomising only one wine in one round as binding. The careful explanation that the money provided to the bidders in the auction represents a fee linked to the cost of participation

\begin{tabular}{|c|c|c|}
\hline & Prosecco DOC (PDO) & $\begin{array}{l}\text { Conegliano valdobbiadene prosecco } \\
\text { DOCG (superior PDO) }\end{array}$ \\
\hline $\begin{array}{l}\text { Area under vines } \\
\text { (hectares) }\end{array}$ & 22,000 & 7,500 \\
\hline Production area & Flat land of Treviso & $\begin{array}{l}\text { Hills between Valdobbiadene and } \\
\text { Conegliano* }\end{array}$ \\
\hline Firm size and tradition & $\begin{array}{l}\text { Mostly medium-large firms with modern } \\
\text { and contemporary heritage }\end{array}$ & $\begin{array}{l}\text { Mostly small family businesses with } \\
\text { historical heritage }\end{array}$ \\
\hline Grape variety & $100 \%$ Glera & $100 \%$ Glera \\
\hline $\begin{array}{l}\text { Production hectares } \\
\text { (tons) }\end{array}$ & 18 & 13.5 \\
\hline $\begin{array}{l}\text { Vineyard labour (yearly } \\
\text { hours) }\end{array}$ & 50 & 450 \\
\hline Pruning and harvesting & Mostly mechanical & Mostly manual \\
\hline $\begin{array}{l}\text { Sparkling production } \\
\text { method }\end{array}$ & Martinotti & Martinotti \\
\hline $\begin{array}{l}\text { Refermentation } \\
\text { duration (days) }\end{array}$ & 30 & 30 \\
\hline $\begin{array}{l}\text { Production (million } \\
\text { bottles sold) }\end{array}$ & 500 & 90 \\
\hline $\begin{array}{l}\text { Sparkling distribution } \\
\text { channels }\end{array}$ & Mostly sold in large-scale retail & Mostly sold in $\mathrm{HoReCa}$ \\
\hline
\end{tabular}

Table 3.

Information provided to participants in the experimental auction

Note(s): * 15 boroughs of the Treviso piedmont 
helped minimise the windfall effect (Carlsson et al., 2013). Problems concerning the order of Distinct quality presentation of wines were avoided by randomisation (List et al., 2011).

The procedure was repeated seven times, involving a total of 99 participants. As shown in Figure 1, each of the seven sessions was divided into seven major phases, requiring approximately $45 \mathrm{~min}$ of participation.

\section{Results}

Table 4 exhibits the mean WTP of the two Prosecco PDO alternatives. The comparison of means showed that, in the reference round, when participants did not receive any information in addition to what they already knew about GIs and had not tasted the wines, the PS-DOCG was the most preferred.

After receiving the additional information, participants still reasonably preferred the PSDOCG, which entailed a systematic decrease in the WTP for P-DOC. In the blind tasting round, the mean WTP remained higher for the PS-DOCG than for the P-DOC, but participants' bids switched back to higher means for the latter than in the first round. The representation of participants' preferences across rounds makes these outcomes explicit (Figure 2).

1. Selection of wines (No. 14)
The Prosecco PDO ("Treviso") and Conegliano Valdobbiadene Prosecco Superior PDO wine samples were
identified for both production areas.

\begin{tabular}{|c|}
\hline 2. Recruitment and selection of participants (No. 99) \\
Administration of a short questionnaire, whereas \\
socio-demographic characteristics were considered in sampling people.
\end{tabular}

\section{Preparation of the BDM's auction}

Administration of the consent form and economic incentive (10 euros) as compensatatory fees for partecipating in the auction (45 minutes); preparation of general procedure, wines and uniform format for the bidders.

\section{BDM's auction: training}

The general procedure for the elicitation of WTP was explained to the participants so that they were fully informed. The procedure and field context were made familiar to the individuals through a trial with a chocolate bar. Participants were asked not to communicate with each other, to be honest in the judgements while the given responses would be checked during the auction.

\section{BDM's auction: rounds}

First round: participants were asked to indicate the maximum WTP for the two PDO's sparkling wines. Second round (following between-subject and within-subject design): each participant received more information about the two products. WTP for the two denominations was requested.

Third round (following between-subject and within-subject design): Participants now tasted the two wines without any sort of information. WTP and hedonic likings for the two denominations was requested.

\section{BDM's auction: randomization}

One round, one product and one price were randomly drawn as per bidding.

\section{BDM's auction: assignment of the incentives to the participants}

Allocation of the economic incentives to participants and the bottle of wine to the winners. 
$\mathrm{BFJ}$ 123,4

\section{6}

Table 4.

Willingness to pay $(€)$ per bottle of wine $(0.75 \mathrm{~L})$ and hedonic liking for Prosecco PDOs before and after receiving information
The effects of information and wine tasting on Prosecco wines exert varying influences on preferences, leading, in the first case, to an increase in the price differential between the PSDOCG and the P-DOC, from $60.2 \%$ in round one to $77.7 \%$ in round two, while in round three, the gap was reduced to $15 \%$. This result means that, on average, participants are willing to pay almost the same price for a bottle of the PS-DOCG when additional information is supplied, while its WTP is reduced by $21.8 \%$ when the first round is compared with the blindtasting round (Table 5).

In contrast, the values of P-DOC WTP with the additional information decrease compared to those in the first round $(-10 \%)$; however, the blind tasting shows a substantial recovery of the P-DOC WTP, with higher values compared to the first round $(+8.9 \%)$, thereby reaching the closest average value, amongst the rounds, to that of the PS-DOCG (Table 6).

The hedonic liking (HL) mean scores for the two GIs show a higher level for the PS-DOCG, although the gap is less significant than that for the WTP. The WTP percentage difference is slightly less than double than the percentage difference in terms of HL score.

Figure 3 shows box-and-whisker plot differences in the mean WTP for the PS-DOCG and the P-DOC across rounds. In particular, in round two, where the difference in $\triangle \mathrm{WTP}$ is larger, the PS-DOCG shows less heterogeneity in participants' judgement compared to the third round. In contrast, in round three, the whiskers extend between $€-2$ and $€ 5.5,87.5 \%$ more than in round two, as there is even more dispersion in the negative $\Delta$ WTP. More

\begin{tabular}{|c|c|c|c|c|c|}
\hline Rounds & & Prosecco PDO & $\begin{array}{l}\text { Prosecco PDO superior } \\
\text { Mean }\end{array}$ & sig & $\begin{array}{c}\Delta(\mathrm{PDO}-\mathrm{Sup} . \mathrm{PDO}) \\
\Delta \%\end{array}$ \\
\hline $1 \mathrm{st}$ & No info (WTP) & 4.92 & 7.88 & $* * *$ & 60.2 \\
\hline 2nd & Information (WTP) & 4.43 & 7.87 & $* * *$ & 77.7 \\
\hline 3rd & Blind tasting (WTP) & 5.36 & 6.16 & $* * *$ & 15.0 \\
\hline $3 r d$ & Blind tasting $(\mathrm{HL})$ & 5.62 & 6.10 & $* *$ & 8.6 \\
\hline
\end{tabular}

Note(s): significance levels according to the paired $t$-test; $* p<0.1,{ }^{* *} p<0.05, * * * p<0.01 ; n=99$ participants. $\mathrm{HL}=$ Hedonic liking assessment (1-9-point Likert scale)
Figure 2.

Mean willingness to pay (€ per bottle, $0.75 \mathrm{~L}$ ) across the rounds for the Conegliano Valdobbiadene Prosecco Superiore DOCG and the Prosecco Spumante DOC

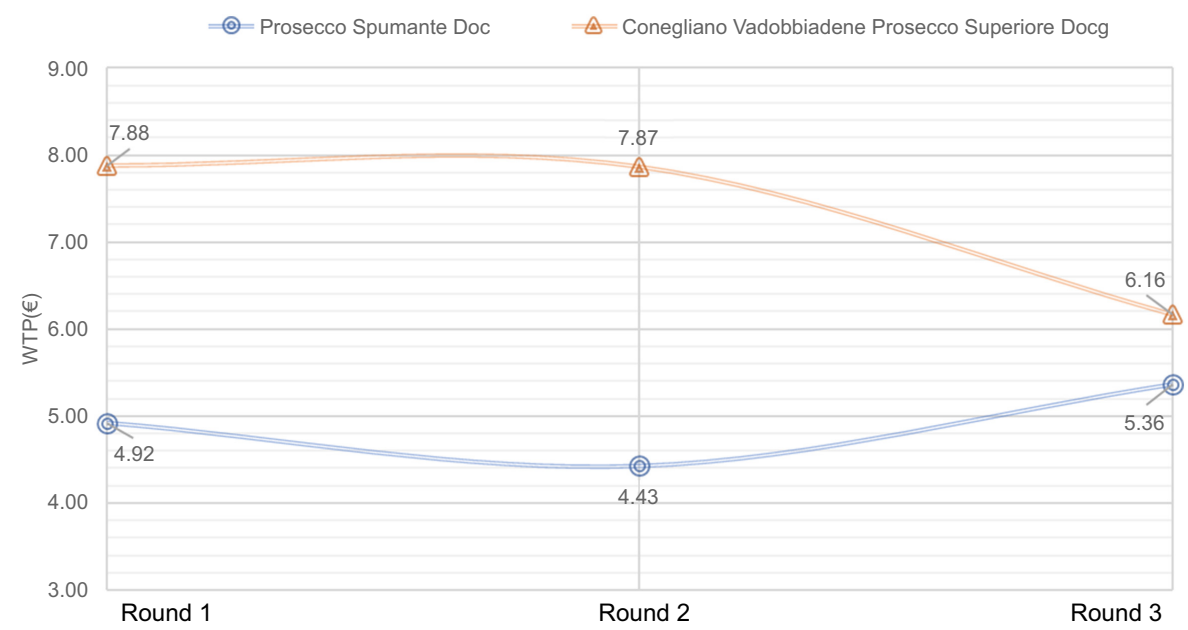


interestingly, in the second round, $\Delta$ WTP's interquartile range goes from $€ 3$ to $€ 4,1.5$ times less heterogeneous than in the third round.

\section{Discussions and conclusions}

This study focussed on the consumers perceived differences between the two Prosecco PDO designations and how the sensory characteristics as well as the provision of additional information may influence consumers' preferences in terms of WTP.

A first observation arises from comparing the WTP difference in the first round and the price gap shown for the tasted wines. Of course, the two mean WTP values are higher than the two mean values of the Prosecco sample, given that they are maximum values and not market prices. However, the two percentage differences are quite similar (60 and 57\%), reflecting the quality and reputation information used in participants' past purchasing experience of sparkling Prosecco (Landon and Smith, 1997), which is largely due to the subset of information on the two PDOs that was available and used in their purchasing decision (Rosen, 1974).

A second point to be stressed is the significant widening of WTP gap following the introduction of additional information, which is exclusively due to decreased WTP for the

\begin{tabular}{lllcc}
\hline Prosecco PDO superior & Mean & sig & $\Delta \%$ Sup. PDO \\
\hline Info effect & round 2-round 1 & -0.015 & & -0.19 \\
Taste effect & round 3-round 1 & -1.718 & $* * *$ & -21.80
\end{tabular}

Note(s): significance levels according to the paired $t$-test; ${ }^{*} p<0.1,{ }^{* *} p<0.05, * * * p<0.01 ; n=99$ participants
Distinct quality hierarchy amongst wines?

\begin{tabular}{llrrr}
\hline Prosecco PDO & Mean & sig & \multicolumn{1}{c}{$\Delta \%$ PDO } \\
\hline Info effect & round 2-round 1 & -0.493 & $* * *$ & -10.02 \\
Taste effect & round 3-round 1 & 0.439 & $* * *$ & 8.92
\end{tabular}

Note(s): significance levels according to the paired $t$-test; ${ }^{*} p<0.1,{ }^{* *} p<0.05, * * * p<0.01 ; n=99$ participants

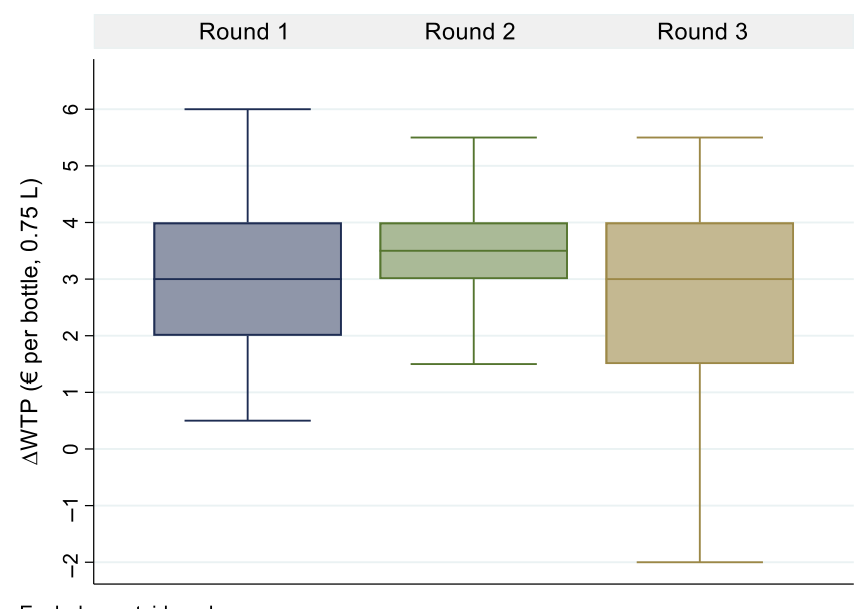

Figure 3. Boxplot of $\Delta$ WTP $(€)$ across rounds between the Prosecco Superior $\mathrm{PDO}$ and the Prosecco PDO

Willingness to pay variation across rounds for the Prosecco

PDO Superior
Willingness to pay variation across rounds for the Prosecco PDO

\section{Excludes outside values}


BFJ

123,4

1488

P-DOC and not to an improved WTP for the PS-DOCG. As with the first point, this fact can be explained mostly by collective reputation variables as relevant elements in the consumers' information set. We can argue that, for consumers, the regional reputation of Prosecco sparkling wine is essentially that of the PS-DOCG, which is strongly rooted in their minds and for which they know both the production methods and the history and tradition associated with it. Therefore, the additional information on this wine did not change its reputation and WTP. In contrast, the additional information about the Prosecco PDO gave most participants the awareness of a less-demanding production technique, a somewhat newer tradition and less appealing vine-growing landscape, all factors that contributed to its reduced WTP.

The third round, though still showing a highly significant WTP predominance of the PSDOCG, rehabilitates the P-DOC, especially in terms of HL, reducing the gap between the two GIs. This result should not be considered unfavourable for the PS-DOCG. Previous blind wine-tasting tests (Goldstein et al., 2008) using non-wine-experts have shown a substantial inability of testers to distinguish positive relationships between wine sensory attributes and price.

The WTP difference - $€ 0.80$ per bottle, or $15 \%$ - can be interpreted as reflecting the minimum quality gap between the two sparkling wines, which is determined exclusively by experience attributes (taste). At the opposite end, the widest WTP difference $-€ 3.44$ per bottle, or $77.7 \%$ - found in the second round can be viewed as the expression of the overall quality when consumers are fully cognisant of all the credence attributes. However, the effect of the latter on the appreciation of the two Proseccos is divergent: for the PS-DOCG, they increase the WTP by almost $28 \%$ above the bottom WTP level defined by its likeability; for the P-DOC, they reduce the WTP by $21 \%$ below the top WTP level defined by its likeability.

Although limited by a somewhat narrow sample constituted mainly by consumers living almost exclusively in the Veneto region, our analysis once again underlines the "superiority" of the PS-DOCG in comparison with the P-DOC. In addition, it supplies useful indications for a promotion strategy for the two collective brands.

Even if we cannot infer general conclusions on the influence of information, we would add the idea that employing a set of ad hoc communication strategies could lead to a process learning effect that raises the possibility of discriminating the ranking at the wine-tasting step and identifying the heterogeneity between the two PDOs (Combris et al., 2009). Indeed, for the PS-DOCG, it appears crucial to effectively communicate the values associated with the production land, tradition, history and any other aspect that increases its image and reputation. This communication is particularly important for markets in which it competes with the other GI and must be differentiated from the latter. At the same time, both the Consortium and producers have to continuously improve the wine's sensorial quality to avoid disappointing feedback following consumption, especially for consumers who already know the other P-DOC.

The P-DOC promotion strategy should be based on two aspects to be communicated. The first is its main strength, i.e. the high value for money of its likeability (the mean price of one HL score is $€ 0.86$, while for the PS-DOCG, it is $€ 1.25$ ) arising from a quite good sensorial level. The second, which is particularly useful for markets in which it competes with the PSDOCG, consists of stressing all the credence features that are shared with the latter (region, Glera variety, winemaking method, etc.) to avoid a negative effect by emphasising the main differences between them.

This study suffers from some limitations that are often frequent in research on WTP and likeability. First, the sample size limits the representativeness concerning the broader population, leading to restrictions in the generalisation of results. Second, despite the attention paid to the sampling characteristics used in the auctions (i.e. limitation to wine drinkers and mainly to non-expert drinkers, consumer sociodemographic information), the recruitment method relied on the population who were conveniently available to participate 
in the study, considering inclusion criteria restricted to regional cohorts inside and outside the two Prosecco PDO areas. Third, although the wines were accurately selected, we can argue that a different set of brands belonging to both the GIs might change their evaluation in terms of likeability, leading to other WTPs in the blind tests. These two reasons suggest the necessity of performing further BDM auctions during wine-tasting experiments in different locations and with other wine sets. Therefore, these wines were not representative of the whole intra-PDO heterogeneity of the two Prosecco PDO alternatives. Fourth, it is also recognised that the choice of wine when operating in a laboratory environment can prompt different evaluations from those given in the context of a real market (Harrison and List, 2004).

Further research might investigate, in other Italian regions and foreign countries, the importance of factors such as consumer socio-demographic characteristics, cultural features and psychological attitudes in affecting both consumer preferences for Prosecco PDO and their purchasing behaviour. In this context, from the producer's perspective, the question arises: how important is the role of sensorial characteristics in highlighting a distinctiveness quality hierarchy across Prosecco PDO sparkling wines for consumers?

\section{Notes}

1. In wine tasting, Prosecco wines have numerous similar elements that represent a source of unclear information for the Prosecco consumer who is not able to perceive intra-PDO sensory differences.

2. According the annual report on the Prosecco PDO wine market, the average ex-cellar price of the PSDOCG wines was mainly concentrated in the super-premium range $(71 \%)$, while the P-DOC wines showed a price positioning between popular premium $(57 \%)$ and premium wines $(43 \%$ - Boatto et al., 2018).

\section{References}

Aprile, M., Caputo, V. and Gallina, G. (2009), "Attitude and awareness of EU quality labels: an analysis of Italian consumers”, Rivista di Economia Agraria, Vol. 64 Nos 3-4, pp. 269-289.

Becker, G.M., Degroot, M.H. and Marschak, J. (1964), "Measuring utility by a single-response sequential method”, Behavioral Science, Vol. 9 No. 3, pp. 226-232, doi: 10.1002/bs.3830090304.

Boatto, V., Barisan, L. and Pomarici, E. (2018), "Struttura produttiva", Rapporto annuale 2018. L'analisi socio-economica attraverso la storia della Denominazione: Valore inestimabile per il futuro della comunità, Conegliano Valdobbiadene Prosecco DOCG, Pieve di Soligo, Italy, pp. 16-31, available at: https://www.prosecco.it/wp-content/uploads/2018/11/RapportoEconomico-Annuale-2018.pdf.

Bohm, P., Lindén, J. and Sonnegård, J. (2012), "Eliciting reservation prices: becker-DeGroot-marschak mechanisms vs. Markets", The Economic Journal, Vol. 107 No. 443, pp. 1079-1089, doi: 10.1111/j. 1468-0297.1997.tb00008.x.

Bruwer, J., Saliba, A. and Miller, B. (2011), "Consumer behaviour and sensory preference differences: implications for wine product marketing", Journal of Consumer Marketing, Vol. 28 No. 1, pp. 5-18, doi: 10.1108/07363761111101903.

Bruwer, J., Lesschaeve, I. and Campbell, B.L. (2012), "Consumption dynamics and demographics of Canadian wine consumers: retailing insights from the tasting room channel", Journal of Retailing and Consumer Services, Vol. 19 No. 1, pp. 45-58, doi: 10.1016/j.jretconser.2011.08.008.

Caracciolo, F. and Furno, M. (2020), "Hedonic functions, heterogeneous consumers, and wine market segmentation", Journal of Agricultural and Resource Economics, Vol. 45 No. 2, pp. 299-316.

Caracciolo, F., D’Amico, M., Di Vita, Pomarici, E., Dal Bianco, A. and Cembalo, L. (2016), "Private vs collective wine reputation", International Food and Agribusiness Management Review, Vol. 19 No. 3, 1030-2016-83139, pp. 191-210. 
BFJ 123,4

Caracciolo, F., Vecchio, R., Lerro, M., Migliore, G., Schifani, G. and Cembalo, L. (2019), "Natural versus enriched food: evidence from a laboratory experiment with chewing gum", Food Research International, Vol. 122, pp. 87-95, doi: 10.1016/j.foodres.2019.03.069.

Carlsson, F., He, H. and Martinsson, P. (2013), "Easy come, easy go", Experimental Economics, Vol. 16 No. 2, pp. 190-207, doi: 10.1007/s10683-012-9326-8.

Cembalo, L., Caracciolo, F. and Pomarici, E. (2014), "Drinking cheaply: the demand for basic wine in Italy", Australian Journal of Agricultural and Resource Economics, Vol. 58 No. 3, pp. 374-391.

Chamorro, A., Rubio, S. and Miranda, F.J. (2015), "The region-of-origin (ROO) effect on purchasing preferences", British Food Journal, Vol. 117 No. 2, pp. 820-839, doi: 10.1108/bfj03-2014-0112.

Charness, G., Gneezy, U. and Kuhn, M.A. (2012), "Experimental methods: between-subject and withinsubject design", Journal of Economic Behavior and Organization, Vol. 81 No. 1, pp. 1-8, doi: 10. 1016/j.jebo.2011.08.009.

Charters, S., Velikova, N., Ritchie, C., Fountain, J., Thach, L., Dodd, T.H., Fish, N., Herbst, F. and Terblanche, N. (2011), "Generation Y and sparkling wines: a cross-cultural perspective", International Journal of Wine Business Research, Vol. 23 No. 2, pp. 161-175, doi: 10.1108/ 17511061111143016.

Combris, P., Bazoche, P., Giraud-Héraud, E. and Issanchou, S. (2009), "Food choices: what do we learn from combining sensory and economic experiments?”, Vol. 20 No. 8, pp. 550-557, doi: 10.1016/j. foodqual.2009.05.003.

Corrigan, J.R. and Rousu, M.C. (2006), "Posted prices and bid affiliation: evidence from experimental auctions", American Journal of Agricultural Economics, Vol. 88 No. 4, pp. 1078-1090, doi: 10. 1111/j.1467-8276.2006.00917.x.

Costanigro, M., Scozzafava, G. and Casini, L. (2019), "Vertical differentiation via multi-tier geographical indications and the consumer perception of quality: the case of Chianti wines", Food Policy, Vol. 83, pp. 246-259, doi: 10.1016/j.foodpol.2019.01.008.

Culbert, J.A., Ristic, R., Ovington, L.A., Saliba, A.J. and Wilkinson, K.L. (2017), "Influence of production method on the sensory profile and consumer acceptance of Australian sparkling white wine styles", Australian Journal of Grape and Wine Research, Vol. 23 No. 2, pp. 170-178, doi: 10.1111/ ajgw.12277.

Dal Bianco, A., Boatto, V., Trestini, S. and Caracciolo, F. (2018), "Understanding consumption choice of prosecco wine: an empirical analysis using Italian and German Homescan data", Journal of Wine Research, Vol. 29 No. 3, pp. 190-203.

Del Rey, R. (2015), "Il mercato internazionale degli spumanti: prospettive di evoluzione". C.I.R.V.E. (Conegliano), available at: http://www.cirve.unipd.it/it/notizie/2015/10/19/Seminari/ index.html.

Depositario, D.P.T., Nayga, R.M., Wu, X. and Laude, T.P. (2009), "Should students be used as subjects in experimental auctions?”, Economics Letters, Vol. 102 No. 2, pp. 122-124, doi: 10.1016/j.econlet. 2008.11.018.

Drichoutis, A.C., Lazaridis, P. and Nayga, R.M. (2008), "The role of reference prices in experimental auctions", Economics Letters, Vol. 99 No. 3, pp. 446-448, doi: 10.1016/j.econlet.2007.09.010.

Galletto, L. (2005), "Marketing the prosecco wine: consumers' attitudes and producers' strategies", Food, Agriculture and the Environment, Economic Issues', F. Angeli, Milano, pp. 179-196.

Gokcekus, O. and Finnegan, C.M. (2017), "Price effects of establishing a new sub-AVA within Oregon's Willamette Valley AVA”, Journal of Wine Economics, Vol. 12 No. 4, pp. 345-353, doi: 10.1017/ jwe.2017.13.

Goldstein, R., Almenberg, J., Dreber, A., Emerson, J.W., Herschkowitsch, A. and Katz, J. (2008), "Do more expensive wines taste better? Evidence from a large sample of blind tastings", Journal of Wine Economics, Vol. 3 No. 1, pp. 1-9, doi: 10.1017/s1931436100000523. 
Gracia, A., Loureiro, M.L. and Nayga, R.M. Jr (2011), "Are valuations from nonhypothetical choice experiments different from those of experimental auctions?", American Journal of Agricultural Economics, Vol. 93 No. 5, pp. 1358-1373, doi: 10.1093/ajae/aar054.

Harrison, G.W. and List, J.A. (2004), “Field experiments”, Journal of Economic Literature, Vol. 42 No. 4, pp. 1009-1055, doi: 10.1257/0022051043004577.

Distinct quality hierarchy amongst wines?

Hoffman, C. (2004), "When consumers buy wine, what factors decide the final purchase", Wine Industry Journal, Vol. 19 No. 2, pp. 82-91.

Johnson, R. and Bruwer, J. (2007), "Regional brand image and perceived wine quality: the consumer perspective”, International Journal of Wine Business Research, Vol. 19 No. 4, pp. 276-297.

Landon, S. and Smith, C.E. (1997), "The use of quality and reputation indicators by consumers: the case of Bordeaux wine", Journal of Consumer Policy, Vol. 20 No. 3, pp. 289-323.

Lange, C., Martin, C., Chabanet, C., Combris, P. and Issanchou, S. (2002), "Impact of the information provided to consumers on their willingness to pay for Champagne: comparison with hedonic scores", Food Quality and Preference, Vol. 13 Nos 7-8, pp. 597-608, doi: 10.1016/s0950-3293(02) 00059-9.

Lee, K., Zhao, J. and Ko, J.Y. (2005), "Exploring the Korean wine market”, Journal of Hospitality and Tourism Research, Vol. 29 No. 1, pp. 20-41, doi: 10.1177/1096348004268195.

Lewis, K.E., Grebitus, C. and Nayga, R.M. (2016), "The Importance of taste in experimental auctions: consumers' valuation of calorie and sweetener labeling of soft drinks", Agricultural Economics, Vol. 47 No. 1, pp. 47-57, doi: 10.1111/agec.12208.

List, J.A., Sadoff, S. and Wagner, M. (2011), "So you want to run an experiment, now what? Some simple rules of thumb for optimal experimental design", Experimental Economics, Vol. 14 No. 4, p. 439, doi: 10.1007/s10683-011-9275-7.

Lombardi, A., Vecchio, R., Borrello, M., Caracciolo, F. and Cembalo, L. (2019), "Willingness to pay for insect-based food: the role of information and carrier", Food Quality and Preference, Vol. 72, pp. 177-187, doi: 10.1016/j.foodqual.2018.10.001.

Lusk, J.L. (2003), "Using experimental auctions for marketing applications: a discussion”, Journal of Agricultural and Applied Economics, Vol. 35 No. 2, pp. 349-360, doi: 10.1017/ S1074070800021313.

Lusk, J.L. and Hudson, D. (2004), "Willingness-to-Pay estimates and their relevance to agribusiness decision making", Applied Economic Perspectives and Policy, Vol. 26 No. 2, pp. 152-169, doi: 10. 1111/j.1467-9353.2004.00168.x.

Lusk, J.L. and Shogren, J.F. (2007), Experimental Auctions: Methods and Applications in Economic and Marketing Research, Cambridge University Press, New York.

Lusk, J.L., Feldkamp, T. and Schroeder, T.C. (2004), "Experimental auction procedure: impact on valuation of quality differentiated goods", American Journal of Agricultural Economics, Vol. 86 No. 2, pp. 389-405, doi: 10.1111/j.0092-5853.2004.00586.x.

Lusk, J.L., Alexander, C. and Rousu, M.C. (2007), "Designing experimental auctions for marketing research: the effect of values, distributions, and mechanisms on incentives for truthful bidding", Review of Marketing Science, Vol. 5 No. 1, p. 0000102202154656161059, doi: 10.2202/15465616.1059 .

Olarte, C., Pelegrín, J. and Reinares, E. (2017), "Model of acceptance of a new type of beverage: application to natural sparkling red wine", Spanish Journal of Agricultural Research, Vol. 15 No. 1, p. 2.

Plott, C.R. and Zeiler, K. (2005), "The willingness to pay-willingness to accept gap, the 'endowment effect,' subject misconceptions, and experimental procedures for eliciting valuations", American Economic Review, Vol. 95 No. 3, pp. 530-545.

Pomarici, E., Barisan, L., Boatto, V. and Galletto, L. (2019), "The prosecco superiore DOCG industry structure: current status and evolution over time", in Alonso Ugaglia, A., Cardebat, J.M. and 
BFJ

123,4

Corsi, A. (Eds), The Palgrave Handbook of Wine Industry Economics, Springer International Publishing, Cham, pp. 421-435.

Porter, M.E. (2008), Competitive Strategy: Techniques for Analyzing Industries and Competitors, The Free Press, New York.

Resano, H., Sanjuán, A.I. and Albisu, L.M. (2012), "Consumers' response to the EU quality policy allowing for heterogeneous preferences", Food Policy, Vol. 37 No. 4, pp. 355-365, doi: 10.1016/j. foodpol.2012.03.006.

Rosen, S. (1974), "Hedonic prices and implicit markets: product differentiation in pure competition", Journal of Political Economy, Vol. 82 No. 1, pp. 34-55.

Rossetto, L. and Gastaldello, G. (2018), "The loyalty structure of sparkling wine brands in Italy", Journal of Wine Economics, Vol. 13 No. 4, pp. 409-418, doi: 10.1017/jwe.2018.43.

Rossetto, L., Boatto, V. and Barisan, L. (2011), "Strategies and interpreting models of a reformed DOC: the prosecco case study", Enometrica, Vol. 4 No. 1, pp. 57-77, available at: http://eum.unimc.it/ riviste/enometrica/4-1-2011-enometrica.

Roth, A.E. and Kagel, J.H. (1995), The Handbook of Experimental Economics, Princeton University Press, Princeton, NJ, Vol. 1.

Rousu, M.C., Huffman, W.E., Shogren, J.F. and Tegene, A. (2004), "Estimating the public value of conflicting information: the case of genetically modified foods", Land Economics, Vol. 80 No. 1, pp. 125-135.

Sáenz-Navajas, M.P., Ballester, J., Peyron, D. and Valentin, D. (2014), "Extrinsic attributes responsible for red wine quality perception: a cross-cultural study between France and Spain”, Food Quality and Preference, Vol. 35, pp. 70-85, doi: 10.1016/j.foodqual.2014.02.005.

Saïdi, M., Ay, J.S., Marette, S. and Martin, C. (2020), "Willingness-to-Pay for reshuffling geographical indications", Journal of Wine Economics, Vol. 15 No. 1, pp. 95-111, doi: 10.1017/jwe.2020.5.

Scarpa, R., Thiene, M. and Galletto, L. (2009), "Consumers WTP for wine with certified origin: preliminary results from latent classes based on attitudinal responses", Journal of Food Products Marketing, Vol. 15 No. 3, pp. 231-248, doi: 10.1080/10454440902973377.

Shogren, J.F., Shin, S.Y., Hayes, D.J. and Kliebenstein, J.B. (1994), "Resolving differences in willingness to pay and willingness to accept”, The American Economic Review, Vol. 84 No. 1, pp. 255-270, available at: http://www.jstor.org/stable/2117981.

Steenkamp, J.B.E.M. (1990), “Conceptual model of the quality perception process”, Journal of Business Research, Vol. 21 No. 4, pp. 309-333, doi: 10.1016/0148-2963(90)90019-A.

Teuber, R. (2011), "Consumers' and producers' expectations towards geographical indications: empirical evidence for a German case study”, British Food Journal, Vol. 113 No. 7, pp. 900-918, doi: $10.1108 / 00070701111148423$.

Thiene, M., Galletto, L., Scarpa, R. and Boatto, V. (2013a), "Determinants of WTP for prosecco wine", British Food Journal, Vol. 115 No. 2, pp. 279-299, doi: 10.1108/00070701311302249.

Thiene, M., Scarpa, R., Galletto, L. and Boatto, V. (2013b), "Sparkling wine choice from supermarket shelves: the impact of certification of origin and production practices", Agricultural Economics, Vol. 44 Nos 4-5, pp. 523-536, doi: 10.1111/agec.12036.

Vecchio, R., Lisanti, M.T., Caracciolo, F., Cembalo, L., Gambuti, A., Moio, L., Siani, T., Marotta, G., Nazzaro, C. and Piombino, P. (2019), "The role of production process and information on quality expectations and perceptions of sparkling wines", Journal of the Science of Food and Agriculture, Vol. 99 No. 1, pp. 124-135, doi: 10.1002/jsfa.9153.

Velikova, N., Charters, S., Fountain, J., Ritchie, C., Fish, N. and Dodd, T. (2016), "Status or fun? A crosscultural examination of young consumers' responses to images of champagne and sparkling wine”, British Food Journal, Vol. 118 No. 8, pp. 1960-1975, doi: 10.1108/bfj-12-2015-0497.

Verdonk, N., Wilkinson, J., Culbert, J., Ristic, R., Pearce, K. and Wilkinson, K. (2017), “Toward a model of sparkling wine purchasing preferences", International Journal of Wine Business Research, Vol. 29 No. 1, pp. 58-73, doi: 10.1108/ijwbr-10-2015-0048. 
Zepeda, L. and Deal, D. (2009), "Organic and local food consumer behaviour: alphabet Theory", Distinct quality International Journal of Consumer Studies, Vol. 33 No. 6, pp. 697-705, doi: 10.1111/j.1470-6431. 2009.00814.x.

Zhao, J. and Kling, C.L. (2004), "Willingness to pay, compensating variation, and the cost of commitment”, Economic Inquiry, Vol. 42 No. 3, pp. 503-517, doi: 10.1093/ei/cbh077.

hierarchy

amongst

wines?

Corresponding author

1493

Luigino Barisan can be contacted at: luigino.barisan@unipd.it

For instructions on how to order reprints of this article, please visit our website:

www.emeraldgrouppublishing.com/licensing/reprints.htm

Or contact us for further details: permissions@emeraldinsight.com 